\title{
ВИЗНАЧЕННЯ ПОНЯТТЯ «ПОЛІТИЧНА ВІДПОВІДАЛЬНІСТЬ»: НАУКОВІ ПОГЛЯДИ ТА ПІДХОДИ ДО ЙОГО ТЛУМАЧЕННЯ
}

Мельник Ю. П.

Необхідним складником демократичного державного правління, відносин народу і влади, громадянського суспільства й держави є політична відповідальність. Є багато конкуруючих визначень політичноі відповідальності, що не сприяє інституціалізації цього поняття та його механізмів у політичній практиці. В науковій літературі є багато класифікацій політичної відповідальності, й використаний нами критерій змістових відмінностей між підходами до визначення цього поняття не є єдиним. Проте, на наш погляд, наведені визначення дозволяють краще окреслити поняття політичної відповідальності, показуючи суміжні підходи до його тлумачення. Тому це сприятиме коректному й більш точному вживанню поняття та подальшій теоретичній розробці і практичному втіленню дієвих механізмів політичної відповідальності.

Ключові слова: політична відповідальність, демократія, держава, громадянське суспільство, вищі органи держави, взаємна відповідальність, державна влада.

Необходимой составляющей демократического государственного правления, взаимоотношений народа и власти, гражданского общества и государства является политическая ответственность. Существует большое количество конкурирующих определений политической ответственности, что не способствует институционализации этого понятия и его механизмов в политической практике. В научной литературе существует большое количество классификаций политической ответственности, и использованный нами критерий содержательных различий между подходами к определению этого понятия не является единственным. Однако, на наш взгляд, приведенные определения позволяют лучше определить понятие политической ответственности, показывая смежные подходы к его толкованию. Следовательно, это будет способствовать корректному и более точному применению понятия и дальнейшей теоретической разработке, а также практическому воплощению действенных механизмов политической ответственности.

Ключевые слова: политическая ответственность, демократия, государство, гражданское общество, высшие органы государства, взаимная ответственность, государственная власть.
Melnyk Yu. P. Definition of the term of political responsibility: scientific views and approaches to its interpretation

A democratic state is distinguished by the existence of a mechanism of political responsibility, under which the imposition of sanctions for irresponsible activities is regulated in most cases not by state coercion, but by the position of the public in general and political parties in particular.

Political responsibility is a necessary component of democratic government, the relationship between the people and the government, civil society and state. There are a large number of competing definitions of political responsibility, which does not contribute to the institutionalization of this concept and its mechanisms in political practice.

Initially, the term "responsibility", first introduced into scientific usage by Alfred Ben, was interpreted as "punishment". In the scientific literature to this day, it is widely believed that political responsibility is strongly associated with legal responsibility. The main reason for this statement is the difficulty of clearly defining the grounds for political responsibility and its specific mechanisms.

There are a large number of competing definitions of political responsibility, which does not contribute to the institutionalization of this concept and its mechanisms in political practice. There are a large number of classifications of political responsibility in the scientific literature, and the criterion used by us for meaningful differences between approaches to the definition of this concept is not the only one. However, in our opinion, the above definitions allow us to better define the concept of political responsibility, showing related approaches to its interpretation. Therefore, it will contribute to the correct and more accurate application of the concept and further theoretical development and practical implementation of effective mechanisms of political responsibility.

Institutions of political responsibility are diverse. The main institutional means of realizing political responsibility of state to civil society are national elections and referendums. Political responsibility of civil society to state is realized through its political institutions, the main of which are political parties, public organizations and local governments. The greatest role in ensuring the stability of democracy is played by the institutions 
of political responsibility in the system of higher bodies of state power and their balance as elements of the system of checks and balances.

Instead, the use of the concept of political responsibility in only one of these contexts without taking into account others leads to its semantic narrowing.

Key words: political responsibility, democracy, state, civil society, highest bodies of state authorities, cross responsibility, state power.

Постановка проблеми та іï актуальність. Демократичну державу відрізняє наявність механізму політичної відповідальності, за якого настання санкції за безвідповідальну діяльність регулюється переважно не державним примусом, а позицією громадськості взагалі й політичних партій зокрема.

Необхідним складником демократичного державного правління, відносин народу і влади, громадянського суспільства й держави $є$ політична відповідальність. Є багато конкуруючих визначень політичної відповідальності, що не сприяє інституціалізації цього поняття та його механізмів у політичній практиці.

Метою статті $\epsilon$ визначення поняття «політична відповідальність», розкриття сутності наукових поглядів та підходів до його тлумачення

Виклад основного матеріалу. Спочатку термін «відповідальність», уперше введений у науковий обіг Альфредом Беном, трактували як «карність». У науковій літературі до сьогодні досить поширеною $є$ теза про те, що політична відповідальність міцно пов'язана з відповідальністю юридичною. Основною причиною такого твердження $\epsilon$ складність чіткого визначення підстав настання політичної відповідальності та конкретних іï механізмів.

У науковому середовищі є різні підходи до розгляду ролі правових норм у закріпленні політичної відповідальності та їі співвідношення з юридичною відповідальністю. Саме це питання найбільше ілюструє розбіжність наукових поглядів на природу політичної відповідальності. Зокрема підкреслюється, що політична відповідальність, на відміну від правової відповідальності, яка лежить у системі відносин «людина та норма», знаходиться в системі відносин «людина та виборець» (за умов отримання мандата на основі виборів) «людина та людина» (за умов отримання мандата шляхом призначення) [4].

Особливо гостро дискутується питання їі розмежування 3 конституційною відповідальністю. Прикладами різних поглядів на ці питання $€$ такі висновки:
- щодо обов'язковості для політичної відповідальності регулювання нормами права; саме забезпечення посилення відповідальності за практичну реалізацію публічно-владних повноважень зумовлює потребу їі переходу в конституційно-правову [6, с. 181];

- розгляду політичної відповідальності через дотримання законності представниками влади [9];

- визначення інституту політичної відповідальності як системи політико-правових норм із передбаченням можливості настання негативних наслідків для суб'єктів політики за неналежну реалізацію законодавчо визначених функцій та повноважень [10, с. 48-49];

- тлумачення політичної відповідальності як специфічного політичного інституту нормативно-регулятивної спрямованості політичної діяльності соціальних суб'єктів.

Водночас в окремих дослідженнях зазначається, що конституційна відповідальність за суттю $\epsilon$ правовою формою політичної відповідальності, регулює відносини припинення владних повноважень, передачу влади внаслідок настання політичної відповідальності суб'єктів, зокрема й за умов відсутності юридичних підстав, а зважаючи виключно на політичні мотиви [5]:

- розкриття політичної відповідальності як специфічного функціонального політичного інституту, в якому розвивається нормативно-регулятивна спрямованість [11, с. 341];

- акцентування на настанні політичної відповідальності за дотримання принципу конституціоналізму під час прийняття та реалізації політичних рішень у процесі управління справами суспільства та держави [12, с. 69];

- виокремлення міри відповідальності на основі відсторонення від влади внаслідок неналежного виконання своїх функцій, однак у цих діях відсутній конституційний делікт (вчинення діï, що суперечить закону), інакше йдеться про конституційну відповідальність [13, с. 58];

- виокремлення головних відмінностей політичної відповідальності від конституційної відповідальності на основі констатації обов'язковості для останньої двох елементів: матеріального - делікт (правопорушення) та процесуального (обов'язковість участі судового органу) [14];

- можливості застосування політичної відповідальності за правопорушення та відсутності таких можливостей, причому друге буває частіше [15, с. 312];

- можливості приведення до інших форм відповідальності внаслідок настання політичної відпо- 
відальності (причому прийняття окремого закону про політичну відповідальність та запровадження його норм пов'язується з підсиленням моральності в організації державної влади) [4].

Унаслідок аналізу наукових досліджень установлено, що до загальних характеристик політичної відповідальності науковці відносять:

- iï можливість впливати на владу, забезпечувати відповідність політичного процесу до вимог суспільства, примушувати владу виконувати схвалені суспільством програми, спонукати владу виконувати умови «договору» між владою й суспільством;

- iї виникнення саме у процесі діяльності різних суб'єктів щодо розроблення та реалізації політики, що має відбивати мету та напрями прогресивного розвитку суспільства $[1$, с. $172 ; 14$; 13, с. $18 ; 19]$. Політична відповідальність розглядається у вимірі організації та розвитку державної влади [2, с. 18].

Здебільшого вона розкривається через поняття обов'язку, відплати, покарання суб'єктів владних повноважень [3; с.18]. До сторін цієї відповідальності відносять політиків, владу, опозицію, народ. Особливо підкреслюється політична відповідальність суб'єктів владних повноважень, які були обрані громадянами на виборах [4].

Для суттєвого розуміння природи політичної відповідальності $\epsilon$ те, що розглядається як важливий інструмент стабілізації політичних відносин, а також запобігання суспільним конфліктам [5]. Крім того, до найбільш характерних рис політичної відповідальності науковці відносять її суб'єктивний характер. Водночас можна виділити кілька вимірів суб'єктивізму. Передусім такий характер пояснюється залежністю цього виду відповідальності від політичної, правової культури населення, розвитку практики оцінювання діяльності органів публічної влади, рівня розвитку політичної системи, зокрема політичних інститутів [6, с. 181].

До передумов суб'єктивного характеру політичної відповідальності також відносять відсутність чітких критеріїв оцінювання в цій сфері, зокрема в тому, що стосується оцінки стану державного управління. Цим, зокрема, пояснюється iï відмінність від юридичної відповідальності [7, с. 144]. Напрями реформування системи місцевого самоврядування в Україні.

Для розкриття змісту суб'єктивності окремо розглядають моральний та психологічний фактори, передусім щодо вимог високого рівня професійної компетентності, почуття обов'язку, патріотизму, усвідомлення суб'єктом владних повноважень своєї причетності до вирішення важливих для життя суспільства питань [8]. Суб'єктивний характер політичної відповідальності відбивається й у визначенні спрямованості предмета політичної відповідальності на важливі для життя суспільства питання, діяльність влади щодо реалізації яких має бути підтримана населенням.

Саме орієнтування на суспільно значущі та сприйняті суспільством проблеми, які вирішуються суб'єктами політичної відповідальності, розглядається як певна гарантія та захист суспільства від суб'єктивізму їхньої діяльності [9].

Серед аргументів дослідників щодо відзначення більш загального змісту політичної відповідальності щодо інституту конституційної відповідальності $\epsilon$ відзначення того, що політична відповідальність, крім органів державної влади, також охоплює питання відповідальності органів місцевого самоврядування, політичних партій, громадських організацій у межах причетності їх до здійснення публічної влади [10, с. 49].

Розглядаючи сутність політичної відповідальності, окремі дослідники акцентують на відзначенні її перспективного (позитивного) характеру, що, на їхню думку, відрізняє ії від юридичної відповідальності [6, с. 180]. Враховуючи те, що основними складниками формування відповідальності політичної особистості $€$ соціально-політичні цінності, моральні принципи та правові норми [8], можна зазначити наступне.

Перспективна форма відповідальності розкриває саморегуляційний складник політичної відповідальності, що базується на політичній культурі, моральних та етичних нормах, демократичних цінностях суспільства. Це, по суті, ціннісні основи діяльності суб'єктів владних повноважень. Для того, щоб ця форма отримала практичне втілення, необхідне закріплення в нормативно-правових документах моральних, етичних норм поведінки, демократичних принципів, що дозволить матеріалізувати цю перспективну форму політичної відповідальності. Важливим аспектом досліджень $\epsilon$ розгляд питання настання під час реалізації політичної відповідальності негативних наслідків та покарання, котрі проявляються у втраті довіри та влади шляхом відкликання, розпуску тощо відповідного суб'єкта. Це належить до головних ознак політичної відповідальності.

Водночас утрата влади може як супроводжуватись подальшим розглядом інших видів відповідальності (конституційної, кримінальної тощо), так і не спричинювати настання іншої відповідальності. Тим самим можна зазначити, що 
політична відповідальність за своїм змістом $\epsilon$ більш широким поняттям, ніж конституційна відповідальність, оскільки регулюється як правовими, так і політичними, а також соціально-психологічними, нормами.

Украй важливим для дослідження $\epsilon$ розгляд індивідуальної та колективної форм політичної відповідальності. Погоджуємось із висновком Ю.А. Нисневича про те, що під час здійснення політичним інститутом тих чи інших колективних дій, відповідно до прийнятих колегіально чи індивідуально рішень, кожен із тих, хто входить до його кадрового складу, $\epsilon$ особисто відповідальним за участь або неучасть у таких діях. Лише за такого підходу має сенс розглядати політичну відповідальність політичного інституту як колективного суб'єкта такої відповідальності [12, с. 63]. На думку дослідника, основою для забезпечення конкретизації суб'єкта відповідальності $€$ визначення строку повноважень, чисельності депутатів, які обираються, персональний склад депутатів.

Дослідження дозволяє дійти висновку про те, що політичну відповідальність можна розглядати як відповідальність «вищого ґатунку», необхідним середовищем для функціонування якої $€$ наявність високих стандартів демократичного суспільства та відповідальності влади перед громадянами на всіх рівнях [16, с. 7].

Інститути політичної відповідальності різноманітні. Основними інституціональними засобами реалізації політичної відповідальності держави перед громадянським суспільством $\epsilon$ загальнодержавні вибори й референдум. Політична відповідальність громадянського суспільства перед державою реалізується через його політичні інститути, основними з яких $€$ політичні партії, громадські організації та органи місцевого самоврядування. Найбільшу роль у забезпеченні стабільності демократії відіграють інститути політичної відповідальності в системі вищих органів державної влади та їх збалансованість як елементів системи стримувань і противаг.

На сучасному етапі державотворчих процесів в Україні це питання $є$ викликом, ціннісним орієнтиром розвитку публічного управління, зокрема місцевого самоврядування. Поглиблення знань за цією проблематикою передбачає розкриття інституціональної та функціонального складника політичної відповідальності в місцевому самоврядуванні.

Зокрема, потребує більш детального розгляду можливість того, щоб політична відповідальність виступала засобом саморегулювання та внутріш- нього цензора в діяльності суб'єктів владних повноважень щодо вирішення питань місцевого значення. Тобто розкриття потенціалу саморегулювання особливо стосується тих аспектів, які не завжди охоплюються правовими нормами, а більше пов'язані з поняттями сумління, моралі, справедливості в діяльності органів публічної влади.

Висновки. На наш погляд, до характеристики поняття політичної відповідальності потрібно відносити й дотримання моральних норм, що запропоноване соціально-моральним підходом, і передбачені регламенти відносин як політиків між собою, так і між політиками та суспільством, що передбачено юридичним підходом, і втримання в політичному «коридорі вибору». Всі ці підходи вказують на важливі аспекти поняття політичної відповідальності, яке ввібрало такі характеристики з огляду на різні сфери застосування і яке може проявити їх у відповідних механізмах. Натомість уживання поняття політичної відповідальності тільки в одному з перелічених контекстів без урахування інших призводить до його змістового звуження.

\section{Література}

1. Балуцька Л.І. Сутність політичної відповідальності: часова тривимірність та суб'єктно-об'єктні особливості. Вісник Львів. ун-ту. Серія філософія. 2011. Вип. 14. С. 166-174. URL: http:// los/article/ viewFile/843/871.publications.Inu.edu.ua/bulletins/ index.php/.

2. Самуйлік М.М. Політична відповідальність: специфіка, структура, функціонування : автореф. дис. ... канд. політ. Наук : 23.00.02 «Політичні інститути та процеси». Одеса, 1997. 24 с.

3. Лескин В.И. Интернет-передача «Обретение смыслов». Тема: «Политическая ответственность». Вып. № 135. Центр Сулакшина (Центр науч. полит. мысли и идеологии). URL: http://rusrand.ru/tv/ meaning/politicheskaja-otvetsvennost 13.07.2017.

4. Сулакшин С.А. Интернет-передача «Обретение смыслов». Тема: «Политическая ответственность». Вып. № 135. Центр Сулакшина (Центр научной политической мысли и идеологи). URL: http: / / rusrand.ru/tv/meaning / politicheskajaotvetsvennost 13.07.2017.

5. Торяник В.М Взаємна політична відповідальність державної влади і громадянина в сучасній правовій державі : автореф. дис. ... канд. політ. наук : 23.00.02 / Дніпропетр. нац. ун-т. Дніпропетровськ, 2006. 17 c. URL: http://disser.com.ua/contents/ 17320.html. 
6. Мельниченко В.І. Політична відповідальність публічно-владних інституцій у системі соціальної відповідальності. Вісник Нац. академії держ. упр. при Президентові України. 2011. Вип. 1. С. 175-183. URL: http://visnyk.academy.gov.ua/wp-content/ uploads/2013/11/2011-1-25.pdf, 18.10.2016.

7. Малиновський В.Я. Словник термінів і понять 3 державного управління. Київ : Атіка, 2005. 240 с.

8. Співак В.М. Політична відповідальність. Юридична енциклопедія: в $6 \mathrm{~m}$. / редкол.: Ю.С. Шемшученко (голова редкол.) та ін. Київ : Укр. енцикл., 2001. Т. 3. Київ; М. 792 с. URL: http://leksika. com.ua/15530910/legal/politichna_vidpovidalnist. 19.07.2017.

9. Словарь по политологии. URL: http:// politics.ellib.org.ua/encyclopedia-term-1384.html, 19.07.2017.

10. Малкіна Г.М. Інститути політичної відповідальності як елементи системи стримувань і противаг. Вісник Київ. нац. ун-ту ім. Т.Г. Шевченка. Філософія. Політологія. 2010. № 100. С. 48. URL: http://papers.univ.kiev.ua/responsibility_as_an_ element_of_checkes_and_balances_system_16959. pdf, 19.07.2017.

11. Халдай І.В. Політична відповідальність влади як складова побудови правової держави. Актуальні проблеми політики: 3б. наук. пр. / редкол.: С.В. Ківалов (керівник авт. кол.), Л.І. Кормич (ред.), М.А. Польовий (відп. секр.) та ін. ; ОНЮА,
Південноукр. центр гендер. проблем. Одеса, 2009. Вип. 37. С. 339-345.

12. Нисневич Ю.А. Политическая ответственность: институциональная постановка проблемы. Полис. Политические исследования. 2013. № 4. C. 62-74. les/File/2013/4/6.pdf, 18.10.2016. Доступ. також у PDF: http://www.politstudies.ru/.

13. Колосова Н.М. Теория конституционной ответственности: природа, особенности, структура : дис. ... д-ра юрид. Наук : 12.00.02. Москва, 2006. 368 c.

14. Сокольщик И. Конституционно-правовая ответственность и политическая ответственность. Основные отличия. Юрклуб. Виртуальный клуб юристов. 21.11.2002. URL: http://www.yurclub.ru/ docs/ other/article24.html, 19.07.2017.

15. Чиркин В.Е. Конституционное право зарубежных стран : учебник / Ин-т гос-ва и права РАН. 8-е изд., перераб. и доп. Москва : Норма; ИНФРА-М, 2013. 528 c.

16. Тарасенко Т.М. Поняття політичної відповідальності в контексті наукових досліджень із місцевого самоврядування. Теорія та практика державного управління. 2017. № 3(58). С. 7.

Мельник Ю. П., заступник начальника Управління аграрної політики в Одеській обласній державній адміністраціі 